Article

\title{
Small GTPases and Stress Responses of voran1 in the Straw Mushroom Volvariella volvacea
}

\author{
Jun-Jie Yan ${ }^{1,+}$, Bin Xie ${ }^{1,+}$, Lei Zhang ${ }^{1}$, Shao-Jie Li ${ }^{2}$, Arend F. van Peer ${ }^{1}$, Ta-Ju Wu ${ }^{2}$, \\ Bing-Zhi Chen ${ }^{1}$ and Bao-Gui Xie ${ }^{1, *}$ \\ 1 Mycological Research Center, College of Life Sciences, Fujian Agriculture and Forestry University, \\ Fuzhou 350002, China; junjie017@163.com (J.-J.Y.); 18705043595@163.com (B.X.); \\ zhanglei311540@163.com (L.Z.); arendvanpeer@gmail.com (A.F.v.P.); cbz_2006@163.com (B.-Z.C.) \\ 2 State Key Laboratory of Mycology, Institute of Microbiology, Chinese Academy of Sciences, \\ Beijing 100080, China; lisj@im.ac.cn (S.-J.L.); wutaju@163.com (T.-J.W.) \\ * Correspondance: mrcfafu@163.com; Tel./Fax: +86-591-8378-9277 \\ + These authors contributed equally to this work.
}

Academic Editor: Jianhua Zhu

Received: 30 June 2016; Accepted: 7 September 2016; Published: 10 September 2016

\begin{abstract}
Small GTPases play important roles in the growth, development and environmental responses of eukaryotes. Based on the genomic sequence of the straw mushroom Volvariella volvacea, 44 small GTPases were identified. A clustering analysis using human small GTPases as the references revealed that $V$. volvacea small GTPases can be grouped into five families: nine are in the Ras family, 10 are in the Rho family, 15 are in the Rab family, one is in the Ran family and nine are in the Arf family. The transcription of voran 1 was up-regulated upon hydrogen peroxide $\left(\mathrm{H}_{2} \mathrm{O}_{2}\right)$ stress, and could be repressed by diphenyleneiodonium chloride (DPI), a NADPH oxidase-specific inhibitor. The number of vvran 1 transcripts also increased upon cold stress. Diphenyleneiodonium chloride, but not the superoxide dismutase (SOD) inhibitor diethy dithiocarbamate (DDC), could suppress the up-regulation of voran 1 gene expression to cold stress. These results combined with the high correlations between gene expression and superoxide anion $\left(\mathrm{O}_{2}{ }^{-}\right)$generation indicated that voran 1 could be one of the candidate genes in the downstream of $\mathrm{O}_{2}{ }^{-}$mediated pathways that are generated by NADPH oxidase under low temperature and oxidative stresses.
\end{abstract}

Keywords: edible fungi; small GTPase superfamily; superoxide anion; abiotic stresses; RT-qPCR

\section{Introduction}

Small GTPases, a group of guanine nucleotide binding protein monomers with molecular weights ranging from 20 to $30 \mathrm{kDa}$, widely exist in eukaryotic cells [1]. Small GTPases (sometimes called Ras superfamily GTPases) can bind to GTP and GDP, switching between the activated (GTP binding) and non-activated (GDP binding) states depending on the binding of different substrates, thereby turning on or off relevant metabolic pathways [2]. The Ras superfamily can be further divided into five families (Ras, Rab, Rho, Ran and Arf) depending on the structures and functions of each constituent [3]. The Ras family is important for cell proliferation, differentiation, apoptosis and the regulation of gene expression [4]; the Rho family is involved in cytoskeleton formation, cell polarity, the cell cycle, the regulation of gene expression and the process of mating in yeast cells [5-7]; the Rab and Arf families play important roles in transport across cell membranes [8-12]; and the Ran family regulates the transportation of proteins and RNA molecules at the nuclear pore and is crucial for nuclear assembly, spindle formation and the regulation of mitosis [13-15].

To date, fungal small GTPases have been annotated and classified in only a few fungi, including Coprinopsis cinerea, Cryptococcus neoformans, Laccaria bicolor, Ganoderma lucidum, Phanerochaete chrysosporium, 
Ustilago maydis, Saccharomyces cerevisiae, Schizosaccharomyces pombe and Schizophyllum commune [3,16-19]. The straw mushroom (Volvariella volvacea) is a major cultivated edible fungus in China. The genomes of two V. volvacea strains, PYd21 and V23, have been sequenced [20,21]. However, the small GTPases in straw mushroom have not yet been annotated or classified. Considering the importance of small GTPases in the growth, development, differentiation and environmental responses of eukaryotes, it is necessary to classify and explore the small GTPases of $V$. volvacea.

The small GTPases of the Ran family are abundant in eukaryotes [4]. Chinnusamy et al. [22] showed that Ran GTPases play an important role in stress responses in plants. Previous studies have also shown that oxidative stress, heat shock, UV irradiation and other abiotic stresses can cause changes in the expression level and cytoplasmic distribution of human Ran GTPase [23]. Similar phenomena have also been observed in yeast [24]. V. volvacea should be cultivated at high temperatures $\left(30-35^{\circ} \mathrm{C}\right)$ and can't grow at low temperature $\left(<15^{\circ} \mathrm{C}\right)$. At low temperature, the mycelium and sporophore are prone to autolysis [20], making it difficult for cultivation and post-harvest preservation. In this study, the small GTPases of $V$. volvacea were annotated based on the genome sequence of the homokaryotic strain PYd21. Only one small GTPase, VvRan1 of the Ran family, was found in V. volvacea. A transcript analysis of voran 1 gene was studied under low temperature and oxidative stress.

\section{Results}

\subsection{Identification of V. volvacea Small GTPases}

A total of 116 putative small GTPase sequences were obtained from the local BLASTP analysis of 11,534 predicted $V$. volvacea amino acid sequences using human RAS-related protein sequences downloaded from the RASOnD database [25] as the reference. Further domain analysis using Pfam revealed 35 sequences containing the PF00071 domain common to Ras, Rho, Rab and Ran, while nine sequences containing the Arf specific-domain PF00025 were identified. Of these, the amino acid sequences for 11 small GTPases were not complete, and the full lengths of their coding sequences could not be obtained by reads re-assembly. Thus, the full-length coding sequences of these small GTPase were amplified and sequenced by Sanger sequencing, which resulted in the full-length coding DNA sequences of these 11 small GTPase and the prediction of their amino acid sequences. By further comparison of the predicted amino acid sequences with the small GTPase databases, two predicted small GTPase sequences (VvRas3 and VvRab5) had extra segments. These extra segments were considered to result from prediction errors and were therefore removed. All of amino acid sequences of the 44 predicted $V$. volvacea small GTPases were obtained and uploaded to GenBank database, the sequences brief information are shown in Table 1.

Table 1. The sequences information of 44 Small GTPase of Volvariella volvacea.

\begin{tabular}{|c|c|c|c|c|c|}
\hline Name & Gene ID_Predicted Method & GenBank ID & Name & Gene ID_Predicted Method & GenBank ID \\
\hline VvArf2 & GME2124_T & KU882138 & VvRab5 & GME5664_g & KX009779 \\
\hline VvArf4 & GME4841_g & KU882140 & VvRab7 & GME7649_g & KU900096 \\
\hline VvArf5 & GME5296_g & KU882141 & VvRab8 & GME7988_g & KU900097 \\
\hline VvArf6 & GME8402_T & KU882142 & VvRab9 & GME8752_g & KU900098 \\
\hline VvArf9 & GME10622_g & KU882145 & VvRab12 & GME11319_T & KU900101 \\
\hline VvRho1 & GME749_g & KU900090 & VvRab13 & GME11465_g & KU900102 \\
\hline VvRho2 & GME1391_g & KU900105 & VvRab14 & GME11526_g & KU900103 \\
\hline VvMitRho & GME1938_g & KU900106 & VvRab15 & GME11774_T & KU900104 \\
\hline VvRho4 & GME3984_G & KU900107 & VvRas1 & GME267_T & KX009781 \\
\hline
\end{tabular}


Table 1. Cont.

\begin{tabular}{cccccc}
\hline Name & Gene ID_Predicted Method & GenBank ID & Name & Gene ID_Predicted Method & GenBank ID \\
\hline VvRho5 & GME4319_g & KU900108 & VvRas2 & GME5033_g & KU900114 \\
VvCdc42 & GME7713_T & KU900109 & VvRas3 & GME8078_g & KX009780 \\
VvRho7 & GME7714_g & KU900110 & VvRas4 & GME8593_A & KU900118 \\
VvRho8 & GME9067_g & KU900111 & VvRas5 & GME10486_g & KU900115 \\
VvRho9 & GME9847_g & KU900112 & VvRas6 & GME11128_g & KU900116 \\
VvRac & GME11424_T & KU900113 & VvRas7 & GME11133_T & KX009782 \\
VvRab1 & GME3051_g & KU900091 & VvRas8 & GME11134_g & KU900117 \\
VvRab2 & GME5340_g & KU900092 & VvRas9 & GME11562_T & AHA61595 \\
VvRab3 & GME5662_g & KU900093 & VvRan1 & GME5409_T & KU882146 \\
\hline
\end{tabular}

"_G" represent for GENSCAN Prediction; “_g” represent for GeneMark-ES Prediction; “_A" represent for Augustus Prediction; "_ $T$ " means the gene intron and exon regions were confirmed by transcriptom data, and the amino acid sequences were identified by ORF finder software.

\subsection{Classification of V. volvacea Small GTPases}

The amino acid sequences of 151 human small GTPases identified by Rojas et al. [3] were downloaded from the RCSB Protein Data Bank [26]. Among these sequences, there were 39 Ras proteins, 22 Rho proteins, 60 Rab proteins, one Ran protein and 29 Arf proteins. The phylogenic analysis of the 44 predicted $V$. volvacea small GTPases using the 151 human small GTPases as references showed that all human and V. volvacea small GTPases were clustered into four large clades (Figure 1). The Ran and Rab family proteins were relatively close and were clustered together in the same clade. The 44 predicted $V$. volvacea small GTPases could be divided into the Ras, Rab, Rho, Ran and Arf families. There were one Ras proteins, 10 Rho proteins (of which one, VvMitRho, was a mitochondrial protein), 15 Rab proteins, one Ran protein and nine Arf proteins.

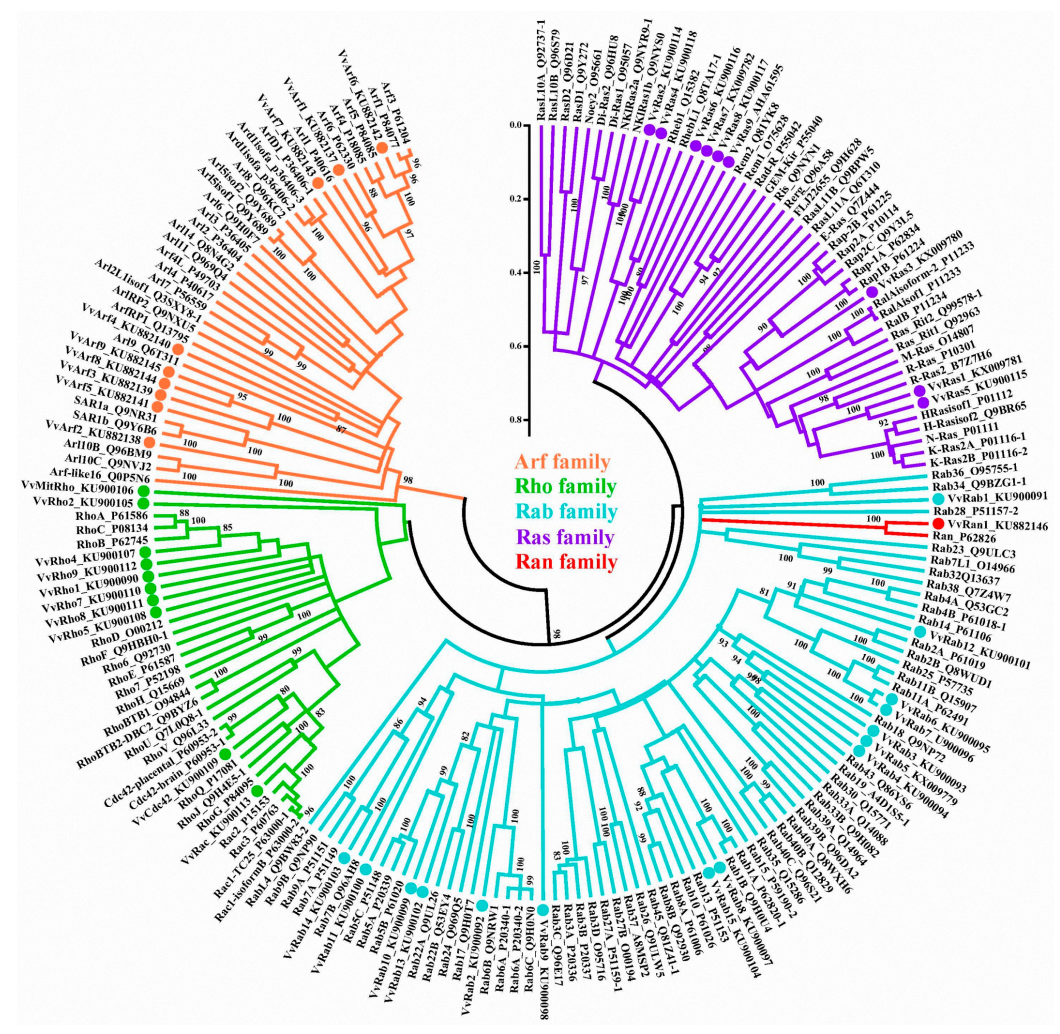

Figure 1. Phylogenetic analysis of human and V. volvacea small GTPases. The 151 human small GTPases were cited based on Rojas et al. [3]. The branches were designated as protein name_uniprot ID. The clades of $44 \mathrm{~V}$. volvacea small GTPases were labeled with the protein name_GenBank ID. The confidence levels of nodes were tested by bootstrapping 1000 times; scores $\geq 80 \%$ were denoted. 
To compare the compositions of small GTPases among mushrooms, the small GTPases from five basidiomycetes Schizophyllum commune H4-8 (v3.0; October 2013; JGI), Laccaria bicolor S238N-H82 (v1.0; March 2005; JGI), Coprinopsiscinerea Okayama7\#130 (v1.0; July 2003; Broad) and Phanerochaete Chrysosporium RP78 (v2.0; February 2005; JGI), were also annotated by using the same method and chosen for the clustering analysis using the neighbor joining method. Results showed that each basidiomycete fungus contains all types of small GTPases (Figure 2; Table 2). The numbers of GTPases in the Rab family are consistent between the different basidiomycetes. The Rab numbers are also relatively greater than those of the GTPases in other families of GTPases in the basidiomycetes except for Laccaria bicolor.

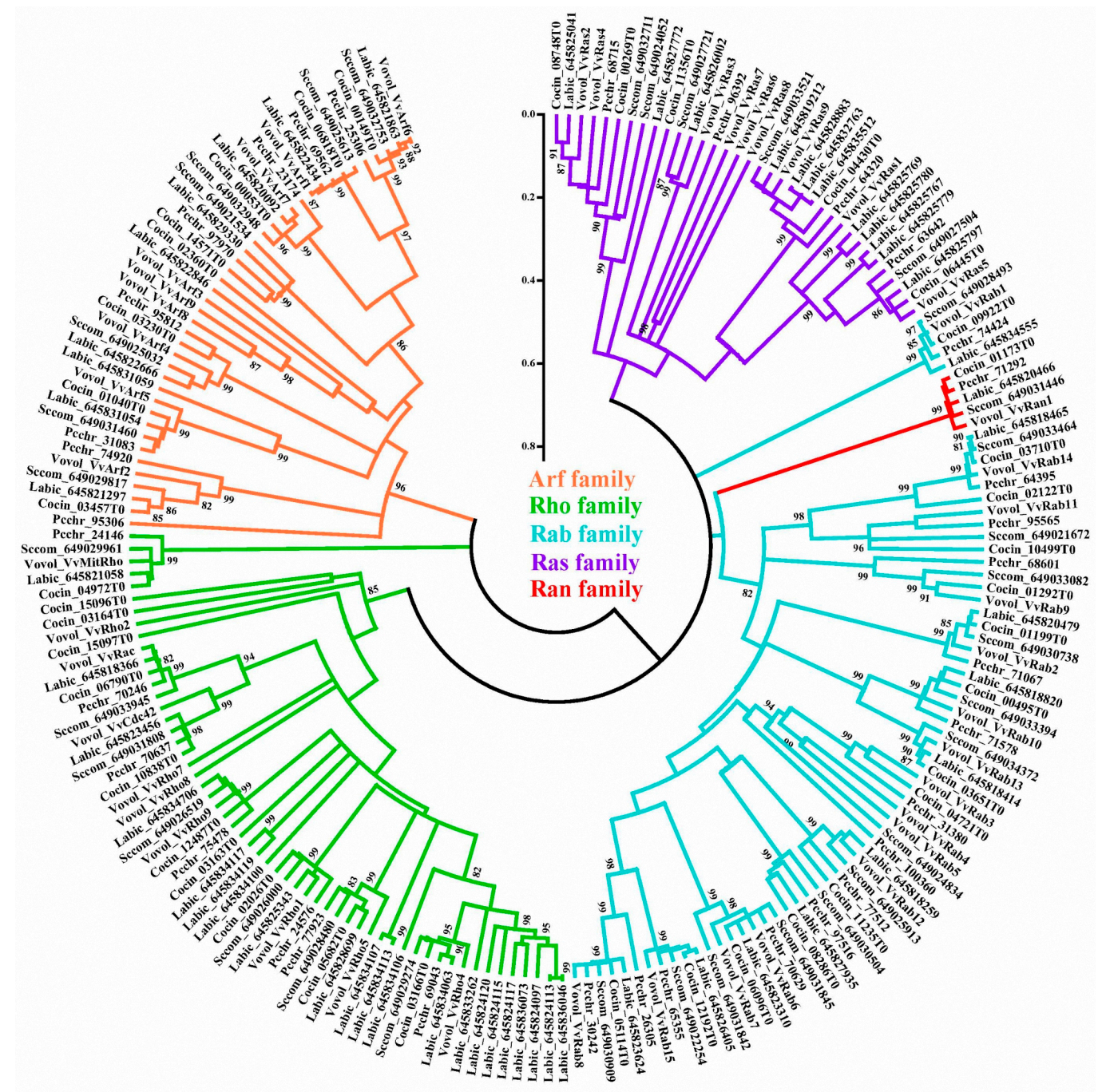

Figure 2. Phylogenetic analysis of small GTPases of 5 basidiomycetes. The clades were labeled with the abbreviated Latin species name, followed by “_predicted gene ID" except for the proteins from Volvariella volvacea, which were labeled with "abbreviated Latin species name_protein name". The following abbreviations were used: Sccom for Schizophyllum commune; Labic for Laccaria bicolor; Cocin for Coprinopsis cinerea; Pcchr for Pchrysosporium chrysosporium; and Vovol for Volvariella volvacea. The confidence levels of the nodes were tested by bootstrapping 1000 times; scores $\geq 80 \%$ were denoted. 
Table 2. Distribution of five small GTPases in the Basidiomycete family.

\begin{tabular}{cccccccc}
\hline \multirow{2}{*}{ Species } & \multicolumn{7}{c}{ Number of Proteins } \\
\cline { 2 - 8 } & Arf & Rho & Ras & Rab & Ran & Total & Reference Number \\
\hline Schizophyllum commune & 7 & 7 & 5 & 14 & 1 & 34 & $34^{\mathrm{a}}$ \\
Laccaria bicolor & 9 & 21 & 12 & 10 & 1 & 53 & $55^{\mathrm{b}}$ \\
Pchrysosporium & 8 & 7 & 4 & 14 & 1 & 34 & $27^{\mathrm{b}}$ \\
chrysosporium & 8 & 11 & 5 & 14 & 1 & 39 & $29 \mathrm{~b}$ \\
Coprinopsis cinerea & 8 & 9 & 9 & 15 & 1 & 44 & This study \\
Volvariella volvacea & 9 & 10 &
\end{tabular}

a represents the number of proteins containing PF00025 (Arf family) or PF00071 (Ras, Rho, Rab and Ran families) as reported by Raudaskoski et al. [18]; ${ }^{b}$ represents the number of proteins containing PF00071 (Ras, Rho, Rab and Ran families) as reported by Rajashekar et al. [17].

\subsection{Phylogenic Analysis of VvRan1}

The $V$. volvacea small GTPase in Ran family was termed VvRan1 in this study. To determine the relationship between VvRan1 and other Ran proteins, the amino acid sequences of VvRan1 (this study) and nine other Ran family proteins, which were downloaded from the RCSB Protein Data Bank were used for the sequence alignment. Figure 3 shows that the Ran family proteins were highly conserved in plants, animals and fungi. All of these sequences had five $\mathrm{G}$ box domains, two effecter regions [27] and an acidic $C$ terminal sequence. The $C$-terminus of each plant Ran protein had two additional amino acid residues compared to those from animals and fungi, suggesting a close molecular evolutionary relationship between the Ran proteins of fungi and animals. To further determine the phylogenic relationship between VvRan1 and other fungal Ran GTPases, the protein sequences of VvRan1 and 22 Ran GTPases from 17 other fungal species were clustered using MEGA5.1 [28]. Figure 4 shows that the Ran GTPases clustered into two large clades. One clade contained only the Ran GTPases from Ascomycota, whereas the other clade contained only the Ran GTPases from Basidiomycota. In the Ascomycota clade, yeast Ran GTPases clustered together, while the Ran proteins of filamentous fungi clustered together. Compared with the Ran proteins of Rhodosporidium toruloides and Ustilago maydis, VvRan1 had a closer relationship with the Ran GTPases of Agaricales fungi. However, VvRan1 could not be clustered into the subclade of the Ran proteins of Agaricales fungi.

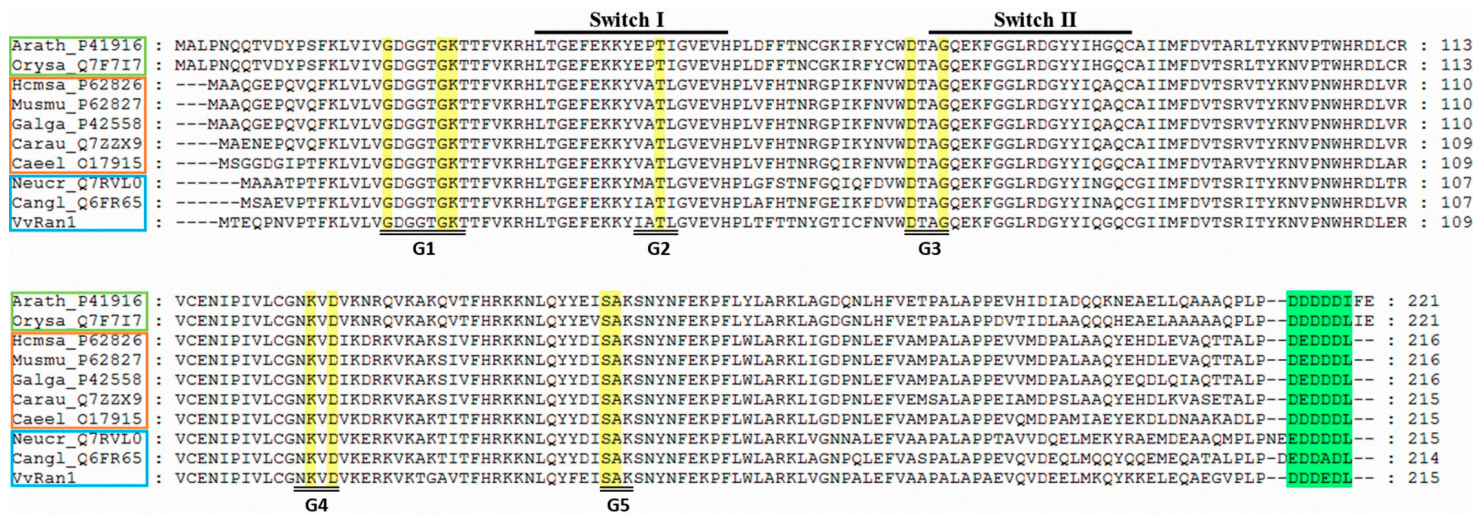

Figure 3. Conservation analysis of Ran amino acid sequences. Sequences were labeled with the abbreviated Latin species names followed by “_PDB ID”. The following abbreviations were used: Arath for Arabidopsis thaliana; Orysa for Oryza sativa; Homsa for Homo sapiens; Musmu for Mus musculus; Galga for Gallus; Carau for Carassius auratus; Caeel for Caenorhabditis elegans; Neucr for Neurospora crassa; and Cangl for Candida glabrata. The Light green box, orange box and light blue box represent the plant, animal and fungal Ran sequences, respectively. The yellow highlights represent five highly conserved $\mathrm{G}$ boxes among the small GTPases. The green highlights represent the acidic $\mathrm{C}$-terminal sequences that are relatively conserved among animals, plants and fungi. 


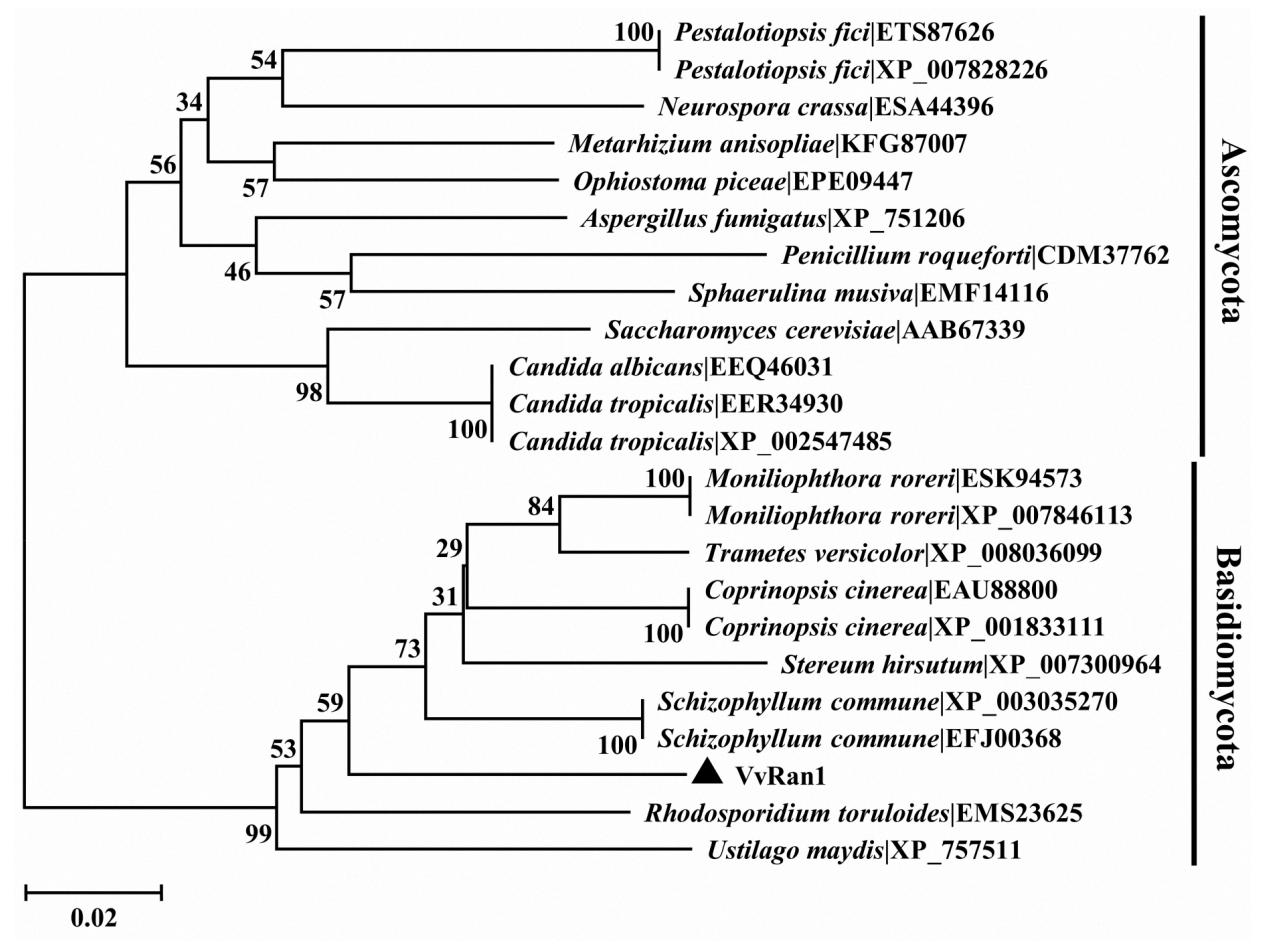

Figure 4. Phylogenetic analysis of $V$. volvacea and other fungal Ran sequences. All sequences except VvRan1 were downloaded from the NCBI database. The clades were named by the Latin species names, followed by the NCBI accession number. The Ran GTPase of $V$. volvacea was labeled by black triangle. The confidence levels of the nodes were tested by bootstrapping 1000 times.

\subsection{The Superoxide Anion $\left(\mathrm{O}_{2}^{-}\right)$Signal Molecular Triggers voran1 to Respone Stresses}

Ran proteins are involved in the stress responses of plants [22], humans [23], and yeast [24]. To test the relationship between vvran1 gene and stresses in Volvariella volvacea, the mycelia were treated with $10 \mathrm{mmol} / \mathrm{L}$ hydrogen peroxide $\left(\mathrm{H}_{2} \mathrm{O}_{2}\right.$, as oxidative stress) or $4{ }^{\circ} \mathrm{C}$ (as cold stress) for $1 \mathrm{~h}$, respectively. RT-qPCR results showed that the voran1 transcript levels were 4.7- and 6.6-fold increased, respectively. These results indicated that voran 1 gene could be regulated by both oxidative and cold stresses (Figure 5A,B).

It is known that NADPH oxidase acts as the critical role in cellular stress responses [29]. It can produce the $\mathrm{O}_{2}{ }^{-}$and then converted into $\mathrm{H}_{2} \mathrm{O}_{2}$ by superoxide dismutase (SOD), both of them can activate specific stresses signaling, also called "redox signaling" [30]. To further understand the vvran1 gene up-regulated mechanism, an NADPH oxidase-specific inhibitor, diphenyleneiodonium chloride (DPI) was used to inactivate the NADPH oxidases [31,32]. RT-qPCR results showed that DPI pre-incubating could completely repress the expression of voran 1 which was up-regulated by $\mathrm{H}_{2} \mathrm{O}_{2}$ and $4{ }^{\circ} \mathrm{C}$ stresses (Figure 5A,B). These results could be taken as evidence that redox signaling via activation of NADPH oxidase is a reason for vvran1 up-regulated.

Moreover, there are two effects that exogenous $\mathrm{H}_{2} \mathrm{O}_{2}$ can cause. One is to permeate through the plasma membrane into cell and activate signaling stresses directly [33], the other is to act as oxidative stress and trigger the cell response by NADPH oxidase. Because the DPI can only block the NADPH oxidase path but cannot prevent $\mathrm{H}_{2} \mathrm{O}_{2}$ into cellular, the positive result of DPI treatment under $\mathrm{H}_{2} \mathrm{O}_{2}$ stress suggested that specific signaling stress activated by $\mathrm{O}_{2}{ }^{-}$should be the reason for voran 1 up-regulated (Figure 5A). To further confirm this mechanism, Diethy dithiocarbamate (DDC), a SOD specific inhibitor that can keep the high level of $\mathrm{O}_{2}{ }^{-}$but the low level of $\mathrm{H}_{2} \mathrm{O}_{2}$ in the cell [34], was added to the incubation solution during cold stress. The results showed that both the intracellular $\mathrm{O}_{2}{ }^{-}$concentration and the vvran 1 expression were maintain at the high level (Figure 5B,C). These 
results further confirmed that $\mathrm{O}_{2}{ }^{-}$but not $\mathrm{H}_{2} \mathrm{O}_{2}$ signal mediates the voran1 up-regulated expression under stress.

$\mathbf{A}$

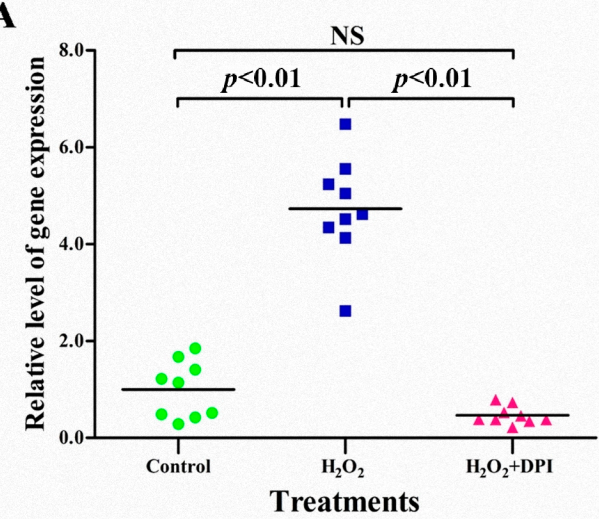

C
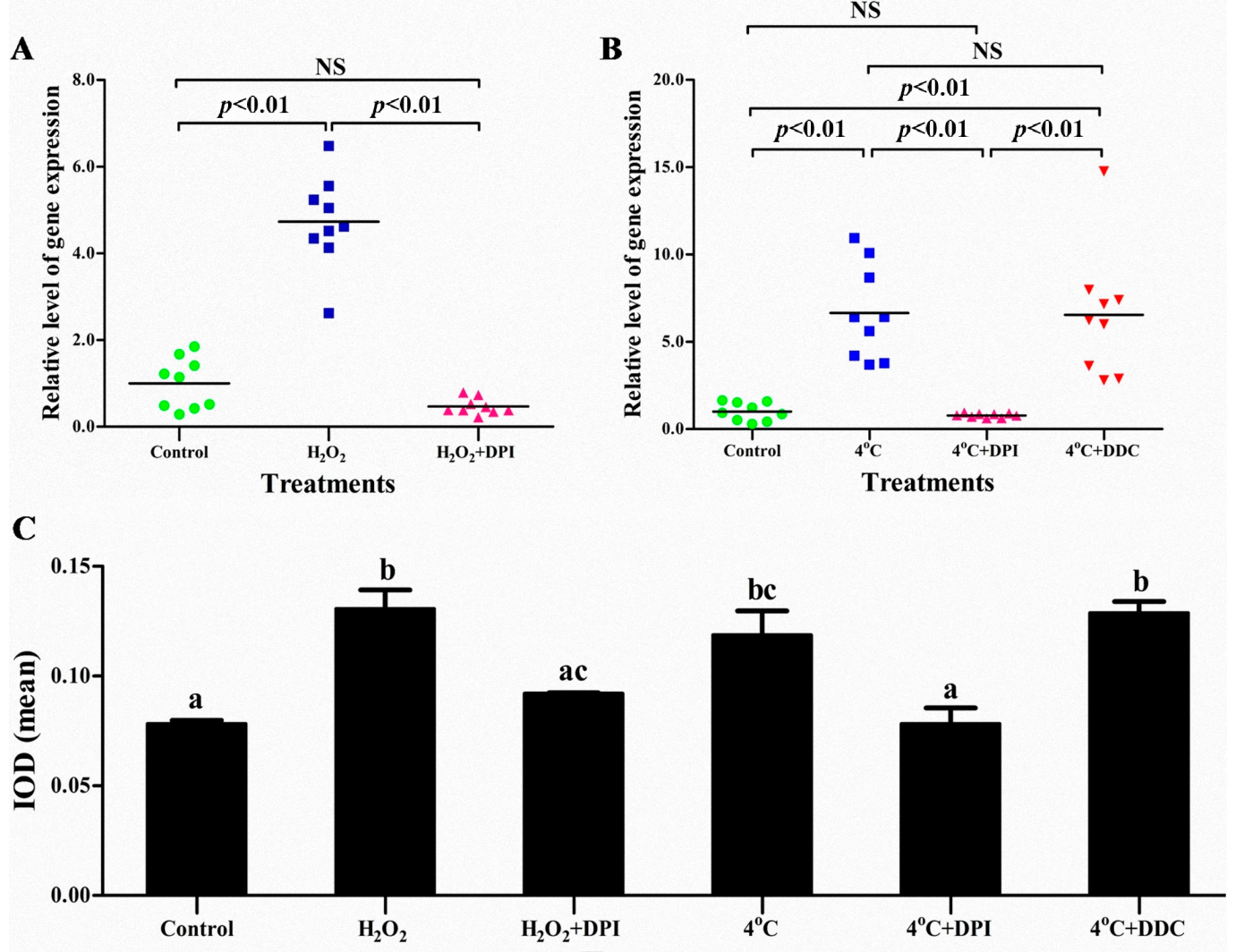

Treatments

Figure 5. Relative expression levels of vvran1 and intracellular superoxide anion accumulation under abiotic stresses: (A) relative expression levels of vvran 1 to hydrogen peroxide $\left(\mathrm{H}_{2} \mathrm{O}_{2}\right)$ stress; (B) relative expression levels of voran1 to cold stress; and (C) the integrated optical density (IOD) mean of superoxide anion $\left(\mathrm{O}_{2}{ }^{-}\right)$detection by nitroblue tetrazolium (NBT) straining. The control, hyphae were incubated in phosphate buffered solution (PBS) buffer for $1.5 \mathrm{~h}$; the $\mathrm{H}_{2} \mathrm{O}_{2}$ and $\mathrm{H}_{2} \mathrm{O}_{2}$ + DPI treatment, hyphae were incubated in PBS buffer or PBS buffer with $50 \mu \mathrm{mol} / \mathrm{L}$ DPI for $0.5 \mathrm{~h}$, respectively, and then were switched to PBS buffer containing $10 \mathrm{mmol} / \mathrm{L} \mathrm{H}_{2} \mathrm{O}_{2}$ and incubated for $1 \mathrm{~h}$; the $4{ }^{\circ} \mathrm{C}$ and $4{ }^{\circ} \mathrm{C}+$ DPI treatment, hyphae were incubated in PBS buffer or PBS buffer with $50 \mu \mathrm{mol} / \mathrm{L}$ DPI for $0.5 \mathrm{~h}$ at $34{ }^{\circ} \mathrm{C}$, respectively, followed by replacing the warm PBS buffer with cold PBS buffer $\left(4^{\circ} \mathrm{C}\right)$ and incubating the hyphae at $4{ }^{\circ} \mathrm{C}$ for $1 \mathrm{~h}$; and the $4{ }^{\circ} \mathrm{C}+$ DDC treatment, hyphae were incubated for $0.5 \mathrm{~h}$ in PBS buffer at $34^{\circ} \mathrm{C}$, followed by exchanging the warm PBS buffer with cold PBS buffer $\left(4{ }^{\circ} \mathrm{C}\right)$ containing DDC and incubating the hyphae at $4{ }^{\circ} \mathrm{C}$ for $1 \mathrm{~h}$. Relative expression levels of vvran 1 in $(\mathbf{A}, \mathbf{B})$ were calculated relative to the transcript level of vvran 1 in the control and three independent experiments with nine independent replicates are shown by different color of shapes. The values of IOD mean in $(C)$ are the means \pm standard deviation $(n=3)$. Statistical testing of significance was performed using a one-way ANOVA and a Bonferroni's posttest, NS means no significance, and the different letters over the columns within a graph denote significant differences $(p<0.05)$.

Additionally, the Pearson correlation coefficient method suggested that the integrated optical density (IOD) mean value of nitroblue tetrazolium (NBT) straining showed in Figure 5C was correlated with voran 1 gene expression $(r=0.901, p<0.05)$, which also indicated that the transcription of voran 1 regulated by oxidative and cold stresses may be mediated by $\mathrm{O}_{2}{ }^{-}$signal molecules. 


\section{Discussion}

The cluster analysis using the neighbor joining (NJ) method grouped the human and $V$. volvacea small GTPases into five well-defined families, indicating that small GTPases within the same family are highly conserved between humans and microbes. However, there were also some highly variable amino acid residues despite the conservation of certain domains, such as the $G$ box, between different families of small GTPases. This finding is consistent with previous results [3]. Because the yeast genome is small, it contains only 29 small GTPases [16]. A previous study showed that using only yeast as the reference for classification results in some of the small GTPases in other filamentous fungi being excluded from their appropriate families [17]. Because human small GTPases have been clearly and completely annotated and classified, we used human GTPases as the references and showed that the clustering analysis based on human small GTPases is suitable for the classification of small GTPases in filamentous fungi with large genomes.

Although Ran is the most abundant small GTPase in eukaryotes and is involved in many cellular metabolic activities, such as the assembly of nuclei, the formation of the spindle and the regulation of mitosis [4,13-15], each basidiomycete contains only one gene encoding a Ran GTPase. In addition, each basidiomycete contains only one Cdc42, one Rac, and one mitochondrial Rho GTPase (Figure 2). The discovery of these genes will be useful for further studies. It is worth noting that Cdc42 and Rac are evolutionarily close, which might explain the similar cellular functions of these two genes [35-37].

$\mathrm{Xu}$ and Cai [38] found that in rice, low temperature stimulation could significantly up-regulate the expression of the Ran gene OsRAN1 and that the over-expression of OsRAN1 could effectively improve cold tolerance in rice. Our results showed that the vvran 1 gene is also sensitive to the cold stress. Therefore, the over-expression of the voran 1 gene may be helpful in developing cold-tolerant mushrooms. Previous studies have shown that environmental stresses can activate membrane-bound NADPH oxidase to produce active ROS signaling molecules (such as $\mathrm{O}_{2}{ }^{-}$and $\mathrm{H}_{2} \mathrm{O}_{2}$ ), thereby inducing relevant genes involved in protecting cells from stress [30,39]. Yan et al. [40] found that $\mathrm{H}_{2} \mathrm{O}_{2}$ can up-regulate the expression of Ran/TC4 in benign mammary epithelial cells but not in malignant cells, suggesting that Ran/TC4 is involved in the antioxidant response of normal cells. Recent studies have suggested that oxidative stress can not only disrupt the distribution of Ran protein in the cell, but can also regulate the Ran-related cellular signal transduction pathways [41,42]. Based on the increased expression of vvran 1 under low temperature and oxidative stresses and the high correlations between gene expression and $\mathrm{O}_{2}{ }^{-}$content, we propose that voran 1 could be one of candidate genes in the downstream of $\mathrm{O}_{2}{ }^{-}$mediated pathways which was produced by NADPH oxidase after stimulated by these abiotic stresses. According to many studies in the literature [39,43-46], intracellular $\mathrm{H}_{2} \mathrm{O}_{2}$ is an important signal molecular that regulates gene expression in the response to environmental stresses. However, the positive result of the experiment using the DPI under oxidative stress $\left(\mathrm{H}_{2} \mathrm{O}_{2}\right.$ stress $)$ and the negative result of the DDC under cold stress suggested that voran 1 may not be regulated by intracellular $\mathrm{H}_{2} \mathrm{O}_{2}$.

It has been reported that the expression of both the OsRAN1 and OsRAN2 genes in rice can be up-regulated by cold stresses [38,47]. These genes can maintain cell division and the progression of the cell cycle by promoting the formation of an intact nuclear envelope and promoting the export of intranuclear tubulin, thereby enhancing the cold tolerance of the cell $[38,47]$. Some other studies have suggested that the abiotic stresses such as free radical nitric oxide production and oxidative stress can mediate Ras guanine nucleotide dissociation; this decreases the levels of intracellular RanGTP and changes its cytoplasmic distribution, thereby leading to cell death [23,41,48]. Furthermore, classical nuclear protein import can be inhibited by oxidative and other forms of stress by reducing the GTP/GDP ratio in Saccharomyces cerevisiae [24]. Our results showed that the expression of voran1 could be rapidly up-regulated by cold and oxidative stresses. This may promote nucleocytoplasmic transport, thereby enhancing the ability of the cells to tolerate stress. Needless to say, more studies are needed to reveal the detailed role of the voran1 gene to abiotic stresses. 


\section{Materials and Methods}

\subsection{Strains}

The dikaryotic strain H1521 (collection number: ACCC52633) was used in all experiments in this study. H1521 is a heterokaryon strain generated by crossing PYd15 (ACCC52631) with PYd21 (ACCC52632), two homokaryon strains with opposite mating types.

\subsection{Genome Sequencing, Splicing and Prediction}

De novo sequencing of the whole genome of PYd21 was performed on the Solexa/Illumina platform at the Shenzhen Huada Gene Research Institute (Shenzhen, China). The genome was assembled using a SOAPdenovo assembler [49]. The NCBI accession number PRJNA171553 was assigned to the genome. A total of 11,534 encoding genes and deduced amino acid sequences were obtained using GeneMark-ES (version 2.3, Atlanta, GA, USA) [50,51].

\subsection{Annotation of Small GTPases}

RAS-related protein sequences were downloaded from the RAS Oncogene Database [25] and locally compared to the 11,534 amino acid sequences using BLASTP after a standardized library was constructed. Amino acid sequences with identities $\geq 30 \%$ and $e$-values $\leq 1 \times 10^{-2}$ were extracted using Perl scripts and submitted to Pfam for domain prediction. Amino acid sequences containing PF00071 or PF00025 and $e$-values $\leq 1 \times 10^{-10}$ were defined as small GTPases.

\subsection{Validation of Sequence Accuracy}

To identify genes encoding small GTPases in $V$. volvacea, the DNA sequences of all V. volvacea small GTPase coding sequences along with the $1000 \mathrm{bp}$ upstream and downstream sequences were used as references to map the reads in $500 \mathrm{bp}$ read pools using the ZOOM software [52]. The reads were obtained from genome sequencing, and the paired end method was used to validate the accuracy of the sequences. The software parameter settings were as follows: the distance of adjacent paired reads was set at 1 to $2000 \mathrm{bp}$; the data were presented in the Illumina format; the number of allowed mismatch bases was set to 0 ; and other parameters were set at default. If all base pairs of a gene were covered by reads, the sequence was considered accurate; if some of the reference sequences did not have corresponding reads, the sequences were verified using Sanger sequencing [53]. All the corrected gene sequences were used as references to map against transcriptome sequence raw reads using ZOOM software, and the software parameter settings were the same with above but the number of allowed mismatch bases was set to 40 to identify the intron region, then, predicted the amino acid sequences by ORF finder online software. If the number of mapping reads was not enough for intron identify, we predicted the gene sequence again using GeneMark-ES [50].

Finally, the integrity and accuracy of the validated amino acid sequences were determined by submitting these sequences to NCBI for BLASTP analysis. The sequences that were obviously longer than the sequences in other species or the sequences that did not align to the sequences of other species were considered to be erroneously predicted, and their extra segments were removed. For sequences that lacked intact conserved domains, we used the GENSCAN (using Vertebrate as the reference species) and Augustus (with Laccaria bicolor as the reference species) websites to predict the alignment again $[54,55]$.

\subsection{Sequence Homology Comparison and Phylogenetic Tree Construction}

After using the MUSCLE program to align the sequences, a neighbor-joining tree was constructed with MEGA5.1 [28]. The structures of the conserved amino acid sequences were colored using the GeneDoc software [56]. 


\subsection{Preparation of Solutions and Stress Treatments}

According to our previous research, $10 \mathrm{mmol} / \mathrm{L} \mathrm{H}_{2} \mathrm{O}_{2}$ or $4{ }^{\circ} \mathrm{C}$ treated for $1 \mathrm{~h}$ can significantly reduce but not completely inhibit the mycelium growth of Volvariella volvacea strain H1521, and hyphal growth was the fastest at $\mathrm{pH} 8$ condition [57].

PBS buffer $(0.02 \mathrm{~mol} / \mathrm{L}, \mathrm{pH} 8)$ containing $10 \mathrm{mmol} / \mathrm{L}$ of $\mathrm{H}_{2} \mathrm{O}_{2}$ was used as an oxidative stress solution. DPI (Sigma, Saint Louis, MO, USA) and DDC (Sigma, Saint Louis, MO, USA) were dissolved in sterile water and diluted to $50 \mu \mathrm{mol} / \mathrm{L}$ and $1 \mathrm{mmol} / \mathrm{L}$ with PBS buffer $(0.02 \mathrm{~mol} / \mathrm{L}$, $\mathrm{pH} 8$ ), respectively. Solutions for cold treatments were kept at $4{ }^{\circ} \mathrm{C}$ while solutions for other treatments were kept at $34{ }^{\circ} \mathrm{C}$ before use. The temperature mentioned in this article were allowed within $0.5^{\circ} \mathrm{C}$ fluctuation.

The $V$. volvacea strain H1521 was used to test the transcriptional models of voran 1 to different stresses. The mycelia were cultured in the solid potato dextrose agar (PDA) medium with glass papers on the surfaces of the PDA plates $(\Phi=6 \mathrm{~cm})$ for three days of incubation at $34{ }^{\circ} \mathrm{C}$ in the dark. To expose the mycelia to different stresses, about ten microliters of sterile PBS buffer $(0.02 \mathrm{~mol} / \mathrm{L}, \mathrm{pH} 8)$ was first added to each plate to completely submerge the colonies in the buffer. The plates were incubated at $34{ }^{\circ} \mathrm{C}$ for an additional $0.5 \mathrm{~h}$ before stress treatment. For the DPI inhibition experiments, the colonies were pre-incubated with the DPI inhibitor solution that was added to the plates instead of PBS buffer. All stress treatments (except for cold stress treatments) were conducted at $34{ }^{\circ} \mathrm{C}$ in the dark for $1 \mathrm{~h}$. For the cold stress treatments, the plates were incubated at $4{ }^{\circ} \mathrm{C}$ in the dark for $1 \mathrm{~h}$.

\section{7. voran1 Transcript Analysis}

After the stress treatment, the mycelia were quickly scraped, blot-dried and stored in a $-80{ }^{\circ} \mathrm{C}$ freezer. The RNA was extracted using an E.Z.N.A. ${ }^{\text {TM }}$ Plant RNA kit (Omega Bio-Tek, Norcross, GA, USA). The first strands of cDNA were synthesized using TransScript ${ }^{\circledR}$ All-in-One First-Strand cDNA Synthesis SuperMix for qPCR (One-Step gDNA Removal) (TransGen Biotech, Beijing, China). Real-time fluorescent quantitative PCR (RT-qPCR) was carried out using TransStart Top Green qPCR SuperMix (TransGen Biotech, Beijing, China) on a CFX96 real-time fluorescence quantitative PCR machine (Bio-Rad, Hercules, CA, USA). The level of expression of the untreated control was used as the reference for calculating the relative expression levels using the $2^{-\Delta \Delta C t}$ method [58]. Glyceraldehyde-3-dehydrogenase (GAPDH) and 18S ribosomal RNA gene (18S $r R N A)$ were used as reference genes. The PCR primers are shown in Table 3.

Table 3. Primers used in real-time quantitative PCR.

\begin{tabular}{cc}
\hline Primer & Sequence $\mathbf{( 5}^{\prime} \mathbf{- 3}^{\prime} \mathbf{)}$ \\
\hline Ran1-F & AGTTCGTCGCTGCTCCTGCTCT \\
Ran1- $R$ & ACCCTCAGCCTGTTCCAGTTCCTT \\
$G A P D H-F$ & CATCTTCCACTGGTGCGGCTAAG \\
GAPDH-R & GGCTTCTCAAGGCGAACGACAA \\
$18 S r R N A-F$ & TCTTGTGAAACTCTGTCGTGCTGGG \\
$18 S r R N A-R$ & TTGCCCACACCCCAAAGCTAATTCG \\
\hline
\end{tabular}

\subsection{Histochemical Detection of $\mathrm{O}_{2}{ }^{-}$}

$\mathrm{O}_{2}{ }^{-}$was visually detected in the mycelia of $V$. volvacea by using NBT (Amresco, Fountain Parkway Solon, OH, USA) as substrate [59]. Briefly, the mycelia on the surfaces of the PDA plates after stresses treatment were killed quickly by liquid nitrogen, after ice melting, the mycelia were incubated with $0.05 \mathrm{~mol} / \mathrm{L} \mathrm{PBS} \mathrm{(pH} \mathrm{7.5)} \mathrm{containing} 0.05 \%$ NBT for $2 \mathrm{~h}$ at the ice-bath condition. The pictures were taken by Nikon P500 digital camera with the same exposure conditions. The computer-assisted genuine color image analysis system (imagepro-plus 6.0) was used to quantify the mean of integrated optical density. 


\subsection{Statistical Analysis}

The significance of gene expression and superoxide anion content among different samples were analysed using the one-way ANOVA of variance with Bonferroni's multiple comparisons test, and the analysis was performed by GraphPad Prism version 5.01 (San Diego, CA, USA). The correlations of gene expression patterns and $\mathrm{O}_{2}{ }^{-}$contents were analyzed using the Pearson correlation coefficient method by SPSS Statistics v20 software with two-tailed test.

Acknowledgments: This work was supported by grants from the National Key Basic Research Program of China (2014CB138302) and the China Agriculture Research System (CARS24). The authors thank the Fujian Edible Fungi Engineering Technology Research Center and the National Fungi Breeding Center (Fujian Branch) for providing the experimental facilities.

Author Contributions: Bao-Gui Xie and Jun-Jie Yan conceived and designed the experiments; Bin Xie, Lei Zhang and Jun-Jie Yan performed the experiments; Jun-Jie Yan, Bin Xie, Bing-Zhi Chen, Ta-Ju Wu and Bao-Gui Xie analyzed the data; Jun-Jie Yan and Bao-Gui Xie drafted the manuscript; and Shao-Jie Li and Arend F. van Peer edited the manuscript. All authors reviewed and approved the final manuscript.

Conflicts of Interest: The authors declare no conflict of interest.

\section{References}

1. Yang, Z. Small GTPases versatile signaling switches in plants. Plant Cell 2002, 14, S375-S388. [PubMed]

2. Falchi, R.; Cipriani, G.; Marrazzo, T.; Nonis, A.; Vizzotto, G.; Ruperti, B. Identification and differential expression dynamics of peach small GTPases encoding genes during fruit development and ripening. J. Exp. Bot. 2010, 61, 2829-2842. [CrossRef] [PubMed]

3. Rojas, A.M.; Fuentes, G.; Rausell, A.; Valencia, A. The Ras protein superfamily: Evolutionary tree and role of conserved amino acids. J. Cell Biol. 2012, 196, 189-201. [CrossRef] [PubMed]

4. Goitre, L.; Trapani, E.; Trabalzini, L.; Retta, S.F. The Ras superfamily of small GTPases: The unlocked secrets. Methods Mol. Biol. 2014, 1120, 1-18. [PubMed]

5. Simon, M.N.; de Virgilio, C.; Souza, B.; Pringle, J.R.; Abo, A.; Reed, S.I. Role for the Rho-family GTPase Cdc42 in yeast mating-pheromone signal pathway. Nature 1995, 376, 702-705. [CrossRef] [PubMed]

6. Arellano, M.; Coll, P.M.; Perez, P. Rho GTPases in the control of cell morphology, cell polarity, and actin localization in fission yeast. Microsc. Res. Tech. 1999, 47, 51-60. [CrossRef]

7. Wennerberg, K.; Der, C.J. Rho-family GTPases: It's not only Rac and Rho (and I like it). J. Cell Sci. 2004, 117, 1301-1312. [CrossRef] [PubMed]

8. Molendijk, A.J.; Ruperti, B.; Palme, K. Small GTPases in vesicle trafficking. Curr. Opin. Plant Biol. 2004, 7, 694-700. [CrossRef] [PubMed]

9. Hutagalung, A.H.; Novick, P.J. Role of Rab GTPases in membrane traffic and cell physiology. Physiol. Rev. 2011, 91, 119-149. [CrossRef] [PubMed]

10. Casanova, J.E.; Hsu, V.W.; Jackson, C.L.; Kahn, R.A.; Roy, C.R.; Stow, J.L.; Wandinger-Ness, A.; Sztul, E. Meeting report-Arf and Rab family G proteins. J. Cell Sci. 2013, 126, 5313-5316. [CrossRef] [PubMed]

11. Pfeffer, S.R. Rab GTPase regulation of membrane identity. Curr. Opin. Plant Biol. 2013, 25, 414-419. [CrossRef] [PubMed]

12. Zhen, Y.; Stenmark, H. Cellular functions of Rab GTPases at a glance. J. Cell Sci. 2015, 128, 3171-3176. [CrossRef] [PubMed]

13. Avis, J.M.; Clarke, P.R. Ran, a GTPase involved in nuclear processes: Its regulators and effectors. J. Cell Sci. 1996, 109, 2423-2427. [PubMed]

14. Dasso, M. The Ran GTPase: Theme and variations. Curr. Biol. 2002, 12, R502-R508. [CrossRef]

15. Arnaoutov, A.; Dasso, M. The Ran GTPase regulates kinetochore function. Dev. Cell 2003, 5, 99-111. [CrossRef]

16. Garcia-Ranea, J.A.; Valencia, A. Distribution and functional diversification of the Ras superfamily in Saccharomyces cerevisiae. FEBS Lett. 1998, 434, 219-225. [CrossRef]

17. Rajashekar, B.; Kohler, A.; Johansson, T.; Martin, F.; Tunlid, A.; Ahrén, D. Expansion of signal pathways in the ectomycorrhizal fungus Laccaria bicolor-Evolution of nucleotide sequences and expression patterns in families of protein kinases and Ras small GTPases. New Phytol. 2009, 183, 365-379. [CrossRef] [PubMed] 
18. Raudaskoski, M.; Kothe, E.; Fowler, T.J.; Jung, E.M.; Horton, J.S. Ras and Rho small G proteins: Insights from the Schizophyllum commune genome sequence and comparisons to other fungi. Biotechnol. Genet. Eng. Rev. 2012, 28, 61-100. [CrossRef] [PubMed]

19. Ren, A.; Cao, P.; Wu, F.; Li, M.; Jiang, A.; Shi, L.; Zhao, M. Systematic characterization of small GTPases gene family in the model medicinal mushroom Ganoderma lucidum. J. Nanjing Agric. Univ. 2015, 38, 923-929.

20. Bao, D.; Gong, M.; Zheng, H.; Chen, M.; Zhang, L.; Wang, H.; Jiang, J.; Wu, L.; Zhu, Y.; Zhu, G.; et al. Sequencing and comparative analysis of the straw mushroom (Volvariella volvacea) genome. PLoS ONE 2013, 8, e58294. [CrossRef] [PubMed]

21. Chen, B.; Gui, F.; Xie, B.; Deng, Y.; Sun, X.; Lin, M.; Tao, Y.; Li, S. Composition and expression of genes encoding carbohydrate-active enzymes in the straw-degrading mushroom Volvariella volvacea. PLoS ONE 2013, 8, e58780. [CrossRef]

22. Chinnusamy, V.; Gong, Z.; Zhu, J.K. Nuclear RNA export and its importance in abiotic stress responses of plants. Curr. Top. Microbiol. Immunol. 2008, 326, 235-255. [PubMed]

23. Yasuda, Y.; Miyamoto, Y.; Saiwaki, T.; Yoneda, Y. Mechanism of the stress-induced collapse of the Ran distribution. Exp. Cell Res. 2006, 312, 512-520. [CrossRef] [PubMed]

24. Stochaj, U.; Rassadi, R.; Chiu, J. Stress-mediated inhibition of the classical nuclear protein import pathway and nuclear accumulation of the small GTPase Gsp1p. FASEB J. 2000, 14, 2130-2132. [CrossRef] [PubMed]

25. Kulsum, U.; Singh, V.; Sharma, S.; Srinivasan, A.; Singh, T.P.; Kaur, P. RASOnD—A comprehensive resource and search tool for Ras family oncogenes from various species. BMC Genom. 2011, 12, 341. [CrossRef] [PubMed]

26. Rose, P.W.; Beran, B.; Bi, C.; Bluhm, W.F.; Dimitropoulos, D.; Goodsell, D.S.; Prlic, A.; Quesada, M.; Quinn, G.B.; Westbrook, J.D.; et al. The RCSB Protein Data Bank: Redesigned web site and web services. Nucleic Acids Res. 2011, 39, D392-D401. [CrossRef] [PubMed]

27. Wennerberg, K.; Rossman, K.L.; Der, C.J. The Ras superfamily at a glance. J. Cell Sci. 2005, 118, 843-846. [CrossRef] [PubMed]

28. Tamura, K.; Peterson, D.; Peterson, N.; Stecher, G.; Nei, M.; Kumar, S. MEGA5: Molecular evolutionary genetics analysis using maximum likelihood, evolutionary distance, and maximum parsimony methods. Mol. Biol. Evol. 2011, 28, 2731-2739. [CrossRef] [PubMed]

29. Jiang, F.; Zhang, Y.; Dusting, G.J. NADPH oxidase-mediated redox signaling: Roles in cellular stress response, stress tolerance, and tissue repair. Pharmacol. Rev. 2011, 63, 218-242. [CrossRef] [PubMed]

30. Ushio-Fukai, M. Compartmentalization of redox signaling through NADPH oxidase-derived ROS. Antioxid. Redox Signal. 2009, 11, 1289-1299. [CrossRef] [PubMed]

31. O'Donnell, B.V.; Tew, D.G.; Jones, O.T.; England, P.J. Studies on the inhibitory mechanism of iodonium compounds with special reference to neutrophil NADPH oxidase. Biochem. J. 1993, 290, 41-49. [CrossRef] [PubMed]

32. Tian, J.; Cheng, Y.; Kong, X.; Liu, M.; Jiang, F.; Wu, Z. Induction of reactive oxygen species and the potential role of NADPH oxidase in hyperhydricity of garlic plantlets in vitro. Protoplasma 2016. [CrossRef] [PubMed]

33. Hooijmaijers, C.; Rhee, J.Y.; Kwak, K.J.; Chung, G.C.; Horie, T.; Katsuhara, M.; Kang, H. Hydrogen peroxide permeability of plasma membrane aquaporins of Arabidopsis thaliana. J. Plant Res. 2012, 125, 147-153. [CrossRef] [PubMed]

34. Siwik, D.A.; Tzortzis, J.D.; Pimental, D.R.; Chang, D.L.; Pagano, P.J.; Singh, K.; Sawyer, D.B.; Colucci, W.S. Inhibition of copper-zinc superoxide dismutase induces cell growth, hypertrophic phenotype, and apoptosis in neonatal rat cardiac myocytes in vitro. Circ. Res. 1999, 85, 147-153. [CrossRef] [PubMed]

35. Lamarche, N.; Tapon, N.; Stowers, L.; Burbelo, P.D.; Aspenström, P.; Bridges, T.; Chant, J.; Hall, A. Rac and Cdc42 induce actin polymerization and G1 cell cycle progression independently of p65 and the JNK/SAPK MAP kinase cascade. Cell 1996, 87, 519-529. [CrossRef]

36. Birukov, K.G.; Bochkov, V.N.; Birukova, A.A.; Kawkitinarong, K.; Rios, A.; Leitner, A.; Verin, A.D.; Bokoch, G.M.; Leitinger, N.; Garcia, J.G. Epoxycyclopentenone-containing oxidized phospholipids restore endothelial barrier function via Cdc42 and Rac. Circ. Res. 2004, 95, 892-901. [CrossRef] [PubMed]

37. Araujo-Palomares, C.L.; Richthammer, C.; Seiler, S.; Castro-Longoria, E. Functional characterization and cellular dynamics of the CDC-42-RAC-CDC-24 module in Neurospora crassa. PLoS ONE 2011, 6, e27148. [CrossRef] [PubMed] 
38. Xu, P.; Cai, W. RAN1 is involved in plant cold resistance and development in rice (Oryza sativa). J. Exp. Bot. 2014, 65, 3277-3287. [CrossRef] [PubMed]

39. Kuźniak, E.; Urbanek, H. The involvement of hydrogen peroxide in plant responses to stresses. Acta Physiol. Plant. 2000, 22, 195-203. [CrossRef]

40. Yan, Y.; Weaver, V.M.; Blair, I.A. Analysis of protein expression during oxidative stress in breast epithelial cells using a stable isotope labeled proteome internal standard. J. Proteome Res. 2005, 4, 2007-2014. [CrossRef] [PubMed]

41. Heo, J. Redox regulation of Ran GTPase. Biochem. Biophys. Res. Commun. 2008, 376, 568-572. [CrossRef] [PubMed]

42. Kose, S.; Imamoto, N. Nucleocytoplasmic transport under stress conditions and its role in HSP70 chaperone systems. BBA-Gen. Subj. 2014, 1840, 2953-2960. [CrossRef] [PubMed]

43. Mariani, D.; Mathias, C.J.; da Silva, C.G.; Herdeiro Rda, S.; Pereira, R.; Panek, A.D.; Eleutherio, E.C.; Pereira, M.D. Involvement of glutathione transferases, Gtt1 and Gtt2, with oxidative stress response generated by $\mathrm{H}_{2} \mathrm{O}_{2}$ during growth of Saccharomyces cerevisiae. Redox Rep. 2008, 13, 246-254. [CrossRef] [PubMed]

44. Wang, X.; Ma, Y.; Huang, C.; Li, J.; Wan, Q.; Bi, Y. Involvement of glucose-6-phosphate dehydrogenase in reduced glutathione maintenance and hydrogen peroxide signal under salt stress. Plant Signal. Behav. 2008, 3, 394-395. [CrossRef] [PubMed]

45. Suzuki, N.; Mittler, R. Reactive oxygen species-dependent wound responses in animals and plants. Free Radic. Biol. Med. 2012, 53, 2269-2276. [CrossRef] [PubMed]

46. Neill, S.J.; Desikan, R.; Clarke, A.; Hurst, R.D.; Hancock, J.T. Hydrogen peroxide and nitric oxide as signalling molecules in plants. J. Exp. Bot. 2002, 53, 1237-1247. [CrossRef] [PubMed]

47. Chen, N.A.; Xu, Y.; Wang, X.; Du, C.; Du, J.; Yuan, M.; Xu, Z.; Chong, K. OsRAN2, essential for mitosis, enhances cold tolerance in rice by promoting export of intranuclear tubulin and maintaining cell division under cold stress. Plant Cell Environ. 2011, 34, 52-64. [CrossRef] [PubMed]

48. Heo, J.; Prutzman, K.C.; Mocanu, V.; Campbell, S.L. Mechanism of free radical nitric oxide-mediated Ras guanine nucleotide dissociation. J. Mol. Biol. 2005, 346, 1423-1440. [CrossRef] [PubMed]

49. Li, R.; Zhu, H.; Ruan, J.; Qian, W.; Fang, X.; Shi, Z.; Li, Y.; Li, S.; Shan, G.; Kristiansen, K.; et al. De novo assembly of human genomes with massively parallel short read sequencing. Genome Res. 2010, 20, 265-272. [CrossRef] [PubMed]

50. Ter-Hovhannisyan, V.; Lomsadze, A.; Chernoff, Y.O.; Borodovsky, M. Gene prediction in novel fungal genomes using an ab initio algorithm with unsupervised training. Genome Res. 2008, 18, 1979-1990. [CrossRef] [PubMed]

51. Meng, L.; Yan, J.; Xie, B.; Li, Y.; Chen, B.; Liu, S.; Li, D.; Yang, Z.; Zeng, X.; Deng, Y.; Jiang, Y. Genes encoding FAD-binding proteins in Volvariella volvacea exhibit differential expression in homokaryons and heterokaryons. Microbiol. Res. 2013, 168, 533-546. [CrossRef] [PubMed]

52. Zhang, Z.; Lin, H.; Ma, B. ZOOM Lite: Next-generation sequencing data mapping and visualization software. Nucleic Acids Res. 2010, 38, W743-W748. [CrossRef] [PubMed]

53. Yan, J.; Guo, L.; Zhao, J.; Xie, B. Sequence characterization and differential expression of a glutathione S-transferase gene vv-gto1 from Volvariella volvacea. Acta Microbiol. Sin. 2014, 54, 71-78. (In Chinese)

54. Burge, C.B.; Karlin, S. Finding the genes in genomic DNA. Curr. Opin. Struct. Biol. 1998, 8, 346-354. [CrossRef]

55. Hoff, K.J.; Stanke, M. WebAUGUSTUS-A web service for training AUGUSTUS and predicting genes in eukaryotes. Nucleic Acids Res. 2013, 41, W123-W128. [CrossRef] [PubMed]

56. Nicholas, K.B.; Nicholas, H.B., Jr.; Deerfield, D.W., II. GeneDoc: Analysis and visualization of genetic variation. Embnet. News 1997, 4, 1-4.

57. Yan, J.; Zhang, Y.; Zhang, L.; Xie, B.; Qiu, Q.; Xie, B. Abiotic stress tolerance ability of Volvariella volvacea strain H1521 generated by a cross between two genome sequencing strains. J. Fujian Agric. For. Univ. 2015, $44,512-515$. 
58. Livak, K.J.; Schmittgen, T.D. Analysis of relative gene expression data using real-time quantitative PCR and the $2^{-\Delta \Delta C t}$ method. Methods 2001, 25, 402-408. [CrossRef] [PubMed]

59. Shinogi, T.; Suzuki, T.; Kurihara, T.; Narusaka, Y.; Park, P. Microscopic detection of reactive oxygen species generation in the compatible and incompatible interactions of Alternaria alternata Japanese pear pathotype and host plants. J. Gen. Plant Pathol. 2003, 69, 7-16. [CrossRef]

(C) 2016 by the authors; licensee MDPI, Basel, Switzerland. This article is an open access article distributed under the terms and conditions of the Creative Commons Attribution (CC-BY) license (http:/ / creativecommons.org/licenses/by/4.0/). 